\title{
Late Jurassic jaw bones of Halecomorph fish (Actinopterygii: Halecomorphi) studied with X-ray microcomputed tomography
}

\author{
Błażej Błażejowski, Paul Lambers, Piotr Gieszcz, \\ Daniel Tyborowski, and Marcin Binkowski
}

\begin{abstract}
New finds of Halecomorphi fish remains from Late Jurassic limestones of Owadów-Brzezinki (Poland) are investigated using X-ray microcomputed tomography (XMT) revealing details of jaw bones for actinopterygian fish histology. Three-dimensional (3-D) reconstruction allows for correct taxonomical verification. The possibility of 3-D printing gives the opportunity for work with a model in any desired scale without risk of damaging the specimen.
\end{abstract}

Błażej Błażejowski. Institute of Paleobiology, Polish Academy of Sciences, Twarda 51/55, 00-818 Warszawa, Poland. bblazej@twarda.pan.pl

Paul Lambers. Universiteitsmuseum Utrecht, Lange Nieuwstraat 106, 3512 PN Utrecht, The Netherlands, p.h.lambers@uu.nl

Piotr Gieszcz. Independent Center for Advanced Research machinic.it, Stawki 4c/10, 00-193 Warszawa, Poland, pjogi@interia.eu

Daniel Tyborowski. Museum and Institute of Zoology, Polish Academy of Sciences, Wilcza 64, 00-679

Warszawa, Poland, d.tyborowski@student.uw.edu.pl

Marcin Binkowski. Department of Computer Science and Materials Science, University of Silesia,

Katowice, Poland, marcin.binkowski@us.edu.pl

Keywords: Halecomorph fish; Late Jurassic; X-ray microcomputed tomography (XMT)

Submission: 14 October 2014. Acceptance: 21 October 2015

\section{INTRODUCTION}

This paper presents the recently discovered jaw bones of halecomorph fish studied with X-ray microcomputed tomography. The bones came from new paleontological site of the Sławno limestones at the Owadów-Brzezinki quarry (Figure 1) about $19 \mathrm{~km}$ south-east of Tomaszów Mazowiecki (Central Poland), where unusually well- preserved fos- sils of latest Jurassic (Late Tithonian) terrestrial and marine organisms (including also remains of pterosaurs, ammonites, horseshoe crabs, decapod crustaceans and insects) were discovered (Błażejowski, 2015; Kin and Błażejowski, 2012, 2014; Błażejowski et al., 2015).

The most interesting feature of the OwadówBrzezinki quarry (Figure 2) is some similarity to the classic Solnhofen lithographic limestone (e.g.,

Błażejowski, Błażej, Lambers, Paul, Gieszcz, Piotr, Tyborowski, Daniel, and Binkowski, Marcin. 2015. Late Jurassic jaw bones of Halecomorph fish (Actinopterygii: Halecomorphi) studied with X-ray microcomputed tomography. Palaeontologia Electronica 18.3.53A: $1-10$

palaeo-electronica.org/content/2015/1354-jurassic-fish-x-ray 


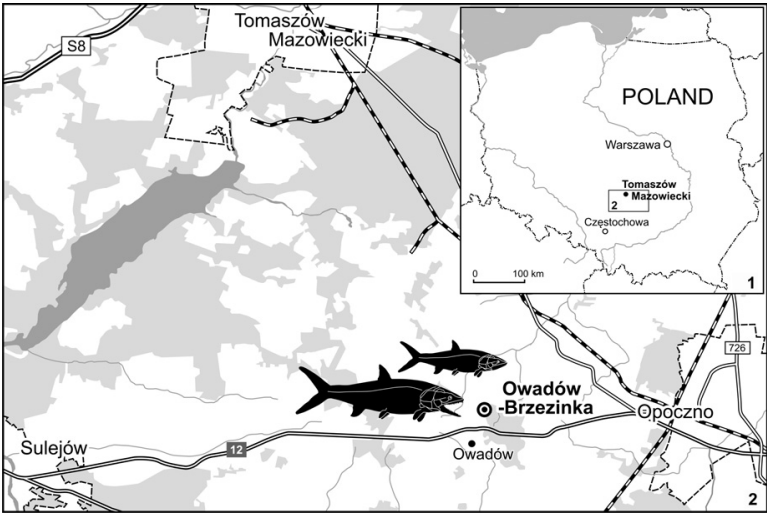

FIGURE 1. Map of Poland (1) with the location of the Owadów-Brzezinki Quarry (2B) near Tomaszów Mazowiecki.

Munnecke et al., 2008). The fossils identified at both localities indicate a similar geological age and environment. The similarities refer to both marine and terrestrial organisms and allow comparative paleontological studies at a previously unattainable level of high taxonomic resolution (Bechly and Kin, 2013; Kin et al., 2012; 2013).

The best preserved, often complete and articulated, specimens of Upper Jurassic actinopterygian fish fossils are known from the late Kimmeridgian to early Tithonian lithographic limestones in the Altmühltal and nearby region (Solnhofen-Eichstätt area and Wattendorf, Bavaria, Germany) (Chellouche et al., 2012; Ebert and Kölbl-Ebert, 2012; Lambers, 1999), and the late
Kimmeridgian lithographic limestone in Nusplingen (Baden-Württemberg, Germany) (Heineke, 1906; Heimberg, 1949; Dietl and Schweigert, 2004), Cerin (south-eastern France) (Wenz et al., 1993) and the nearby locality of Orbagnoux (Sauvage, 1893). The fauna from the lower Tithonian lithographic limestone of Canjuers, France (Fabre et al., 1982; Peyer et al., 2014) appear to be very simliar. More or less complete and articulated fish specimens are also known from Upper Jurassic strata of England (e.g., Woodward, 1893, 1895, 1897, 1915-1917; Jain and Robinson, 1963). An overview is given in Dineley and Metcalf (1999).

From other regions in Europe mainly fragmentary remains, such as vertebra and skull fragments, but more often scales and teeth have been described. From Switzerland the small Tithonian fish fauna of Solothurn (teeth, scales) is known, which is comparable to the fauna's from Southern Germany (Müller, 2011). Pictet and Jaccard (1860) described fish remains (teeth, scales) from the Upper Jurassic of Neuchatel in Switzerland. Fricke (1876) described a fish fauna (pycnodont teeth and a single articulated specimen; see also Kriwet, 2008; Licht, 2011) from the Upper Jurassic near Hannover, Northwestern Germany. Kriwet (1998, 2000, 2002, 2005) and Klug and Kriwet (2012) reported fish remains from the Upper Jurassic of Portugal and Spain. Fragmentary fossils are known from several localities in France (e.g., Sauvage, 1902; Priem, 1912, 1917; Pharisat, 1975; Cuny et al., 1991; Wenz et al., 1987; Vullo et al., 2014,

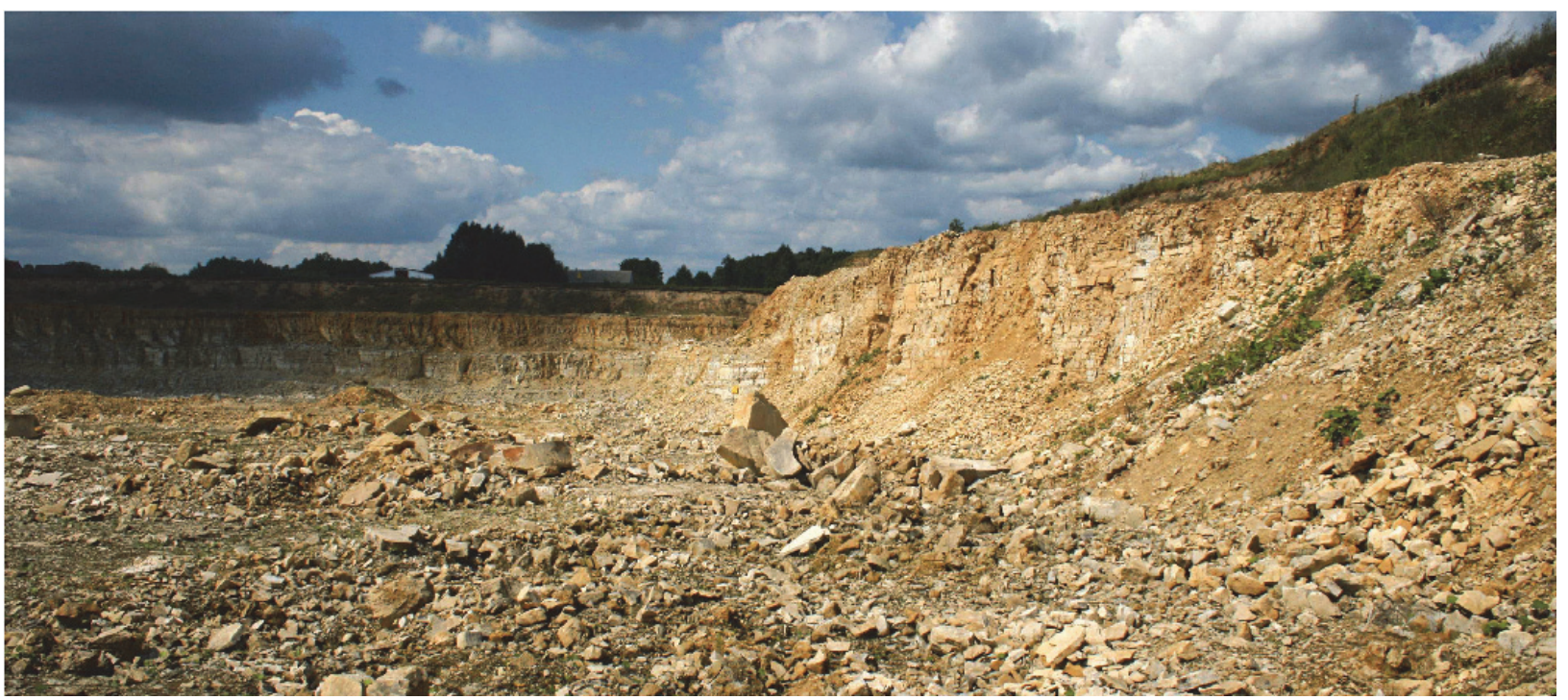

FIGURE 2. Panoramic view of the highest level of exploitation in Owadów-Brzezinki quarry (i.e., unit III and most fossiliferous 'Corbulomima horizon' occurring in the middle of the quarry wall). 


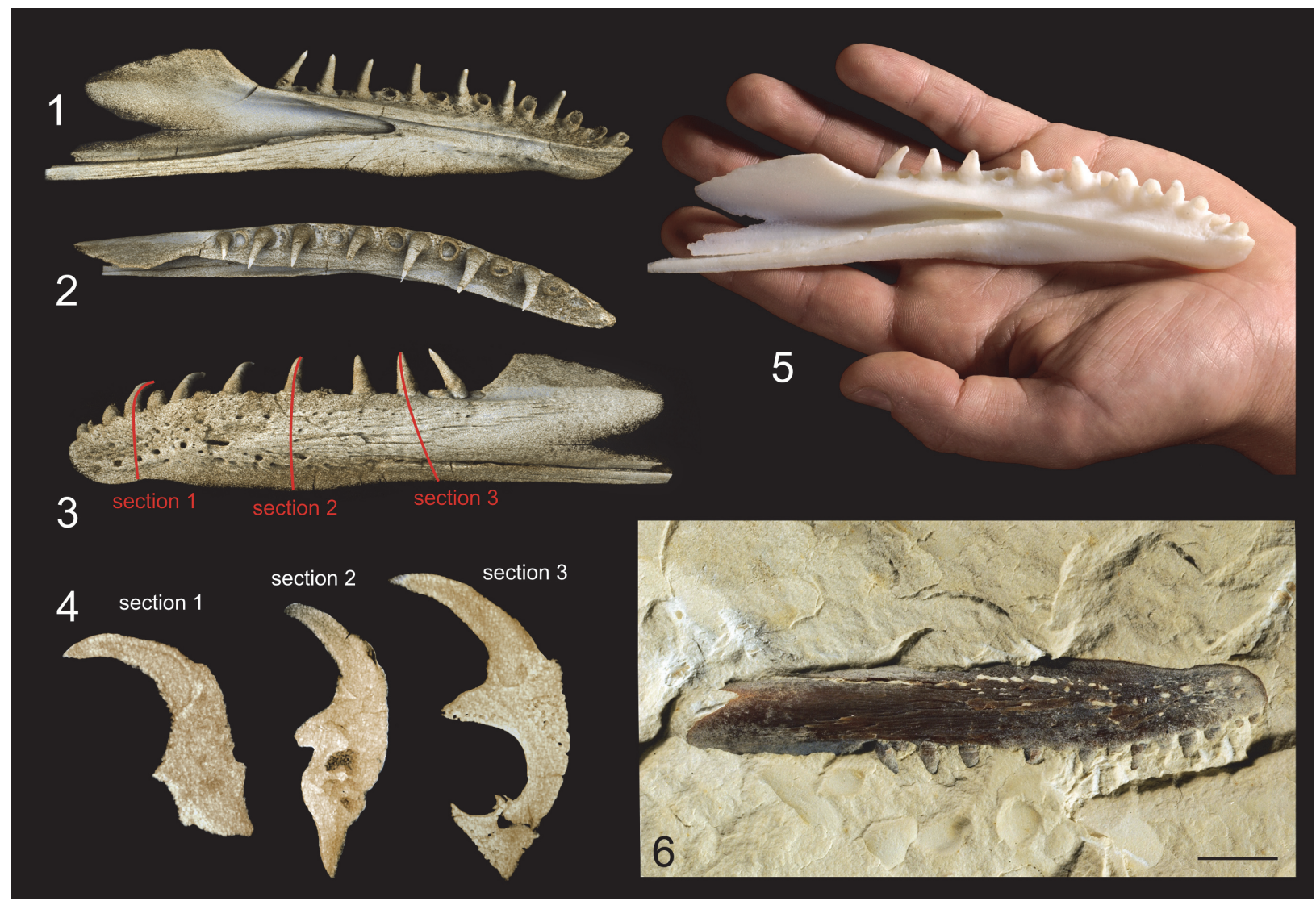

FIGURE 3. Jaw bone of osteichthyan fish Furo sp. (ZPAL P.16/O-B/1): 1-2. 3-D model of 'virtual fossils'-a different view of the same specimen after digital processing and analysis of tomographic data. 4. vertical sections of Furo sp. teeth. 5. 3-D printed dentary - 'virtual fossils'. 6. specimen in piece of limestone (scale bars equal $10 \mathrm{~mm}$ ).

Cavin, 2010) and also from the Tithonian of Italy (Gemmellaro, 1871; Bassani, 1885). Most of these descriptions deal with caturid teeth, lepidotid scales and teeth and pycnodont teeth. Mudroch and Thies (1996) and Thies and Mudroch (1996) were the first to present detailed descriptions based on fish teeth from the Kimmeridgian of Oker in Northwestern Germany.

The Owadów- Brzezinski quarry near Tomaszow Mazowiecki (Central Poland) is an outcrop of Late Tithonian strata. It may be considered as a close stratigraphic equivalent to the Early Tithonian sediments of the Solnhofen area in Bayern, Germany. Fragmentary fish fossils from Owadow-Brzezinski have previously been figured (Kin and Błażejowski, 2012, 2013). In the present paper two jaw bones will be described in more detail.

Since the preparation of specimens from the rock in any conventional means was almost impossible due to risk of unrecoverable destruction, we used X-ray microcomputed tomography (XMT), a non-invasive tool (Błażejowski et al., 2011) that allows us to look into the internal structure of investigated specimens, and after computer processing, to render a 3-D model (Figures 3,4) with further possibility of generating virtual cross-sections in any plan through teeth bones (Figures 3.4, 4.3). The quality of XMT imaging revealed details important for histology studies, which may be a ground for later comparative studies.

\section{GEOLOGICAL AND PALEONTOLOGICAL SETTINGS}

The study area is located approximately 18 $\mathrm{km}$ southeast of Tomaszów Mazowiecki (Central Poland). At the moment, the Owadów-Brzezinki quarry is the only place in extra-Carpathians Poland where the Upper Tithonian strata are available to study (the classic locality Brzostówka is now within the Tomaszów Mazowiecki town limits and inaccessible; quarries in Pomerania are flooded) (Kin et al., 2013). The exposed carbonate sequence belongs to the Kcynia Formation and can be divided into four successive units. Unit I is 


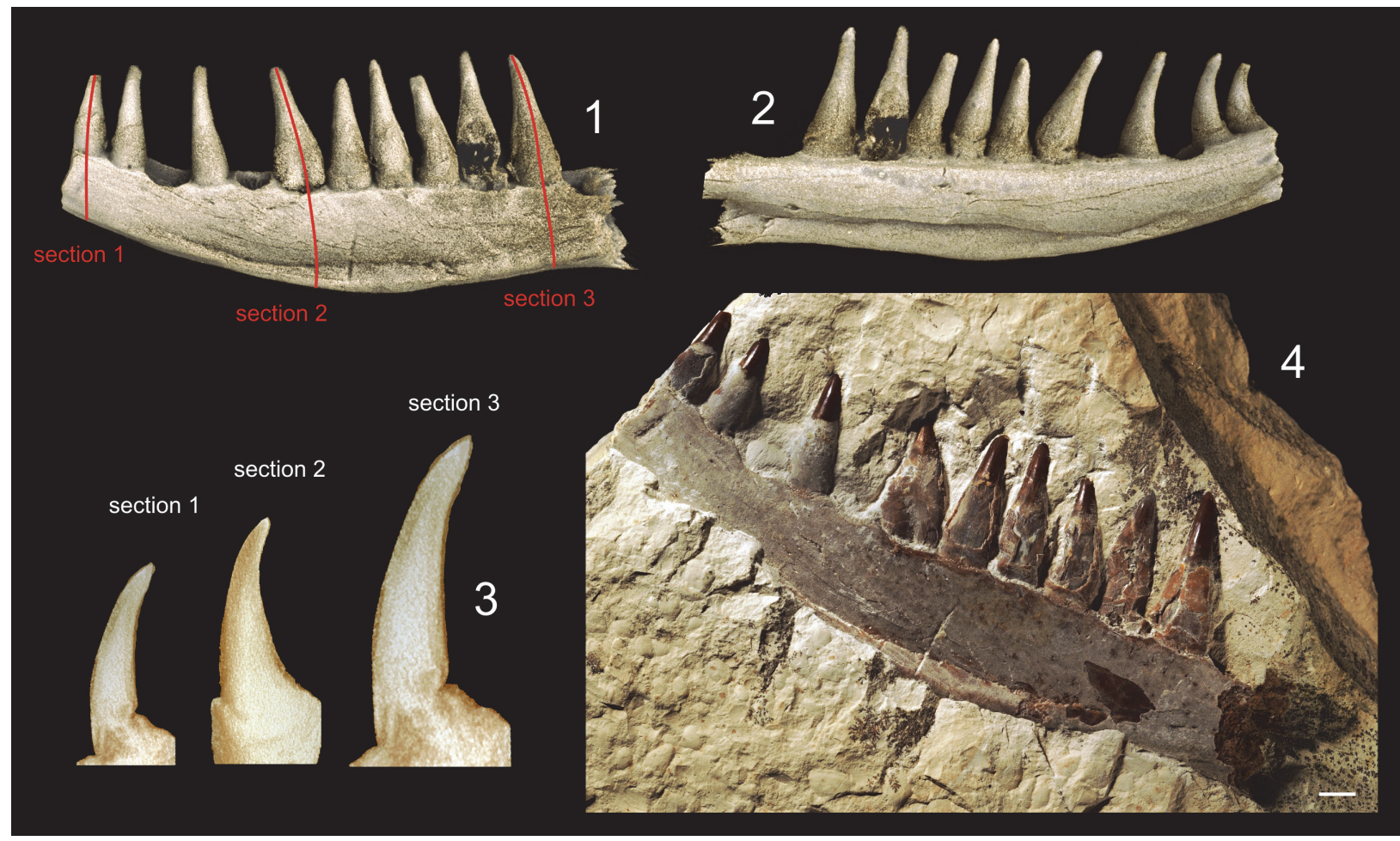

FIGURE 4. Maxillary bone of osteichthyan fish Caturus sp. (ZPAL P.16/O-B/2): 1-2. reconstruction of 3-D 'virtual fossils' - the same specimen after digital processing and analysis of tomographic data (scale bars equal $10 \mathrm{~mm}$ ). 3 . vertical sections of Caturus sp. teeth. 4. just after discovery.

composed of indistinctly laminated massive finegrained limestone ( $\sim 6.6 \mathrm{~m}$ total thickness) with $\mathrm{Del}-$ toideum delta, which forms a few beds of $40-80$ $\mathrm{cm}$ thickness. The overlying c. 2 meters thick unit II is represented by thinly-bedded, fine-grained limestones with occasional distinctive parallel lamination and mass occurrence of calcareous polychaete tubes in one horizon. Within this part of the profile quite common specimens of decapod crustaceans (lobsters) were found. Unit III, c. 15.6 $\mathrm{m}$ thick, is highly fossiliferous and has yielded the specimens that are the subject of this study. Unit $\mathrm{IV}$, c. $2.3 \mathrm{~m}$ in thickness, the top being not exposed, is developed as organodetrital limestone rich in Nanogyra oysters, bryozoans and serpulids. They often form small bioherms. In general, units I, II and III probably represent a transition from an offshore to nearshore, perhaps lagoonal, setting, whereas unit IV bears evidence of a return to more open marine conditions. Below the Kcynia Fm yellowish marls and marly clays of the Pałuki Formation occur.

The uppermost part of the unit (III) is highly fossiliferous, with a horizon of finely bedded finegrained limestones at its base (also called the 'Corbulomima horizon'), dominated by small opportu- nistic bivalve Corbulomima. It follows that the 'Corbulomima horizon' in the higher portion of the section (i.e., unit III), from which jaw bones of actinopterygian fishes originate, was laid down in a very shallow marine basin, which had rather limited links with the open sea (Kin et al., 2013). The constant proximity of the open sea is indicated by occasional finds of ammonites of the genus Zaraiskites (Semenov). Other fossils are rare and represented by exceptionally well-preserved horseshoe crabs, disarticulated remnants of various marine and land arthropods (including decapods, beetles, dragonflies and grasshoppers) and moulds of ammonite shells. Moreover, teeth, bones and rarely partially articulated skeletons of various vertebrates occur.

\section{METHODOLOGY}

$\mathrm{X}$-ray microcomputed tomography (XMT), is an imaging technique, which detects differences in the attenuation of an X-ray beam propagating through a solid object, and as a result detailed information about internal structure is obtained. This data after computer processing allows us to reconstruct a virtual 3-D model of studied bones 
(Figures 3,4 ), and after removing the background from the images by thresholding, a set of virtual cross-sections through teeth can be generated (Figures 3.4, 4.3) (Błażejowski et al., 2013; Sutton et al., 2014). We used the most effective methods for digital processing and analysis of tomographic data, enabling the construction of isosurface-based and volume-based 3-D 'virtual fossils', which can be manipulated and dissected interactively. The resulting images are similar to traditional ones obtained by destructive slicing, and the resolution here is limited by voxel size of computed model, reaching $22.4 \times 22.4 \times 22.4 \mu \mathrm{m}$. The collected material is housed at the Institute of Paleobiology, Polish Academy of Science in Warsaw (ZPAL P.16/ O-B).

\section{DESCRIPTION}

\section{Specimen A}

Specimen $(A)$ is the left dentary of the lower jaw of an actinopterygian fish. It has previously been figured in Kin and Błażejowski (2012, figure 10 ) and Kin et al. (2013, figure 5A) as a ?Pleurosaurus $\mathrm{sp}$. The bone is slender and elongate, 3.4 $\mathrm{cm}$ long and slightly curved inwards (Figure 3 ). The ventral border slightly undulates. The outer surface is striated and wrinkled near the dentigerous border. The pores of the sensory canal are obvious. The bone forms a blunt, rounded anterior symphysial region. The dentary consists of an anterior dentigerous portion and posteriorly a pronounced coronoid process. The dentigerous portion is 2.1 $\mathrm{cm}$ long and about $6 \mathrm{~mm}$ high halfway its length. The coronoid process is $4 \mathrm{~mm}$ high. The dorsalmost point of the coronoid process is at the level of dorsal tips of the teeth. It seems that the coronoid process is damaged, and a part is broken off posterodorsally. The posterior border that sutures with the angular is deeply V-shaped invaginated and has a posterior ventral process that projects further posteriorly than the posterior border of the coronoid process.

There are seven spaced, pointed and conical teeth that are strongly recurved inwards almost bending over, and eight broken or incomplete teeth.

Dimensions, outlook, visible details, internal structure, composition. All teeth have an acrodin crown, without lateral keels. The acrodin is a typical enameloid tissue in actinopterygians. It is usually found at the tip of the tooth and is called "cap enameloid" or "acrodin cap" (Ørvig, 1978; Sasagawa et al., 2009; Shellis and Miles, 1974).
The triangular crown is markedly narrower than the shaft. The bases of the teeth are broad and flattened laterally. The teeth are about $2 \mathrm{~mm}$ long. Seven teeth are complete and eight are broken off or incomplete, and only their bases are preserved. These are the teeth in the positions 1-3, 5, 7, 9, 11 and 14. Lane and Ebert (2012) describe a similar situation in a specimen of Furo muensteri, in which, besides complete teeth, incomplete teeth or tooth bases are present and also isolated acrodin caps. The dentigerous border bends down slightly at the level of the eighth tooth and forms a round anterior edge. In the lateral side of the bone, below the six anterior teeth six pores of the sensory canal are present, the canal running parallel to the dentigerous border. From the level of the seventh tooth the sensory canal runs more ventrally in the dentary. Posteriorly from about the level of the tenth tooth the canal is housed in a groove. Medially there is a meckelian groove that runs form posterior to anterior.

Identification. The original identification in Kin and Błażejowski (2012) and Kin et al. (2013) of the jaw bone as a ?Pleurosoaurus sp. is erroneous. The general shape of the dentary, elongated and with a relatively long dentigerous border and pronounced coronoid process, is as known from halecomorph fishes (e.g., see figures in Grande and Bemis, 1998; Lambers, 1994, 1998). To the Halecomorphi belong the Parasemionotiformes (e.g., Watsonulus from Madagascar, Ospia from East Greenland and species from China, see Quanguo, 2009), lonoscopiformes (e.g., lonoscopus, Furo), and Amiiformes, the latter including the Caturidae (Amblysemius, Caturus) and Amiidae, (recent Amia calva and its closest fossil relatives, such as Pachyamia, Solnhofenamia and Amiopsis) (Chalifa and Tchernov, 1982; Grande and Bemis, 1998; Martín-Abad and Poyato-Ariza, 2013). Throughout the Mesozoic many halecomorph genera have been described worldwide, but from the Paleocene onwards they are restricted to the Amiinae (Cyclurus and Amia) only (Martín-Abad and Poyato-Ariza, 2013; Poyato-Ariza and Martín-Abad, 2013).

The height of the coronoid process might be a distinctive feature. In the present specimen the coronoid process and the teeth are of approximately the same height. This is comparable to the lower jaw figured in a specimen of 'Furo' microlepidotes (Lambers, 1998, figure 5). In Solnhofenamia, Amiopsis and Furo muensteri the coronoid process seems higher than the tips of the teeth (Grande and Bemis, 1998; Lambers, 1994, pers.obs.; Lane 
and Ebert, 2012). In Amblysemius the tips of the teeth and the coronoid process are approximately at the same level. But in all these figured specimens the outline of the posterior part of the dentary and coronoid is partly obscured by other bones, such as the maxilla, which makes an exact observation difficult.

In figures 43-45 of Grande and Bemis (1998) the height of the coronoid process of the dentary of Amia, with respect to the much lower teeth, is clearly visible.

The deep V-shaped invagination of the posterior border and the long ventral posterior portion are conspicuous. In a specimen of 'Furo' microlepidotes a deeply invaginated posterior border of the dentary, with a ventral process that extends slightly further posteriorly than the posterior border of the coronoid process has been figured (Lambers, 1998, figure 5).

In Solnhofenamia the posterior border is only a little invaginated, or in some specimens not invaginated at all and rather convex (Grande and Bemis, 1998). In Amiopsis lepidota the posterior border is deeper invaginated than in Solnhofenamia, especially in the specimen in figure 361 in Grande and Bemis (1998). But the ventral portion of the dentary does not proceed beyond the posterior border of the coronoid process. In Amblysemius the dentary is slightly invaginated (Lambers, 1994, figure 3; Grande and Bemis, 1998, figure 405). In Furo muensteri the dentary sutures posterodorsally along an interdigitating zig-zag structure with a long posteriorly projected ventral portion (Lane and Ebert, 2012, figure 4).

The shape of the teeth, with a crown clearly narrower than the shaft, is similar to that figured of teeth of Ionoscopus (Mudroch and Thies, 1996). But the crown lacks keels, whereas lonoscopus teeth have two small mesial and distal keels (see also Kriwet, 1998; Prasad et al., 2004). Caturus teeth have a distinctive arrowhead shaped crown with large lateral keels (Mudroch and Thies, 1996). Among amiids only the Vidalamiinae have keeled crowns. Keeled crowns have not been described in species of Furo.

The number of teeth 'Furo' microlepidotes, Furo muensteri Solnhofenamia elongata, Amiopsis lepidota, Amblysemius pachyurus, is comparable, all these have about 13-15 teeth in the lower jaw.

Considering the shape and relative dimensions of the dentary and the characteristics of the dentition as outlined. The specimen is tentatively identified as cf. 'Furo' microlepidotes. 'Furo' micro- lepidotes is known from the limestones of Solnhofen (Lambers, 1998).

\section{Specimen B}

This fossil is figured in Kin and Błażejowski (2012, figure 9) and Kin et al. (2013, figure 5B) as a dentary bone of Caturus sp. The specimen is interpreted as a fragment of a left maxilla, anteriorly and posteriorly incomplete (Figure 4). The fragment is around $5,9 \mathrm{~cm}$ long. This indicates a large fish of at least 1 meter long. Nine teeth are more or less completely preserved, and in three teeth only the sockets are visible. The teeth are roughly between $1 \mathrm{~cm}$ long and $0,5 \mathrm{~cm}$ broad. All teeth are longer than the depth of the supporting bone. They are conical, with a broad and laterally compressed, slightly indented base. All teeth have an acrodin cap. The most anterior tooth is best preserved and shows a small, arrow cap with anterior and posterior keels. The dorsal border of the bone slightly undulates.

Identification. The arrow shaped crowns of the teeth with anterior and posterior flanges resembles those of the halecomorph Caturus (Mudroch and Thies, 1996).

The specimen resembles the maxilla of the large Portlandian $C$. cliftoni figured by Woodward (1895, pl. VII, 5, pers. obs.) in that the teeth are longer than the depth of the supporting bone and somewhat slender, but it differs in that they are more widely spaced. From the contemporaneous Upper Jurassic German localities C. giganteus is known, of which specimens of up to 1 meter are collected. The maxillary teeth of $C$. giganteus are however not much longer than the depth of the supporting bone (Lambers, 1994, figure 3). The specimen cannot be determined more precisely than as Caturus sp.

\section{DISCUSSION}

Besides irreversible damage of investigated specimens, one of the most important disadvantages of traditional sectioning is very limited information about volumetric dependencies within the internal structure (histology). X-ray tomography with proper images post processing allows generation of a 3-D model in a form of "virtual fossil" can be manipulated, measured and dissected interactively (Błażejowski et al., 2011). It is also possible to print a reconstructed shape on a 3-D printer in actual size or any desired magnification (Figure 3.5), with all internal structure retained. Sample visualization (3-D model) of the discussed dental bones are shown in Supplemental Materials. 
A detailed projection of investigated fossil, including parts that are hidden in rock, (Figure 3.6) allows us to identify the taxonomy to the genus level. It turns out that first, preliminary identification after examining visible fragments of specimen as a mandible of aquatic sphenodontian Pleurosaurus ex gr. goldfussi (Kin et al., 2013) was wrong. Current study indicates that the specimen is a dentary bone of halecomorph fish Furo sp. (Figure 3).

Both jaw fragments belong to halecomorph fishes known from the Upper Jurassic deposits from Europe and from the Tithonian limestone of Solnhofen in particular. The limestone of OwadówBrzezinski is stratigraphically close to Solnhofen, being about $5 \mathrm{Ma}$ older. Preliminary analysis of its fauna has revealed that the land and marine macrofauna of both localities is very similar. The presently described jaw bones that most probably belong to species known previously only from Solnhofen strongly support this view.

\section{ACKNOWLEDGMENTS}

This work was supported by the Polish National Science Centre (grant number 2012/07/B/ ST10/04175). The funders had no role in study design, data collection and analysis, decision to publish, or preparation of the manuscript. No additional external funding was received for this study. We sincerely thank the three anonymous reviewers for their insight full comments on our manuscript.

\section{REFERENCES}

Bassani, F. 1885. Avanzi di pesci oolitici nel Veronese. Atti della Società Italiana di Scienze Naturali, 23(1):142-163.

Bechly, G. and Kin, A. 2013. First record of the fossil dragonfly family Eumorbaeschnidae from the Upper Jurassic of Poland. Acta Palaeontologica Polonica, 58(1):121-124.

Błażejowski, B. 2015. The oldest species of the genus Limulus from the Late Jurassic of Poland. 3-14. In Carmichael, R.H., Botton, M.L., Shin, P.K.S., and Cheung, S.G. (ed.), Changing global perspectives on biology, conservation, and management of horseshoe crabs. Springer, New York 2015.

Błażejowski, B., Binkowski, M., Bitner, M.A., and Gieszcz, P. 2011. X-ray microtomography (XMT) of fossil brachiopod shell interior for taxonomy. Acta Palaeontologica Polonica, 56(2):427-428.

Błażejowski, B., Duffin, C., Gieszcz, P., Małkowski, K., Binkowski, M., Walczak, M., McDonald, S.A., and Withers, P. 2013. Lower Triassic Saurichthys (Pisces, Actinopterygii) teeth from Spitsbergen, with comments on their stable isotope composition $\left(\delta^{13} \mathrm{C}\right.$ and $\left.\delta^{180}\right)$ and X-ray microtomography. Polish Polar Research, 34(1):23-38.

Błażejowski, B., Gieszcz, P., Brett, C.E., and Binkowski, M. 2015. A moment from before $365 \mathrm{Ma}$ frozen in time and space. Scientific Reports, 5, 14191; doi: 10.1038/srep14191 (2015).

Cavin, L. 2010. Diversity of Mesozoic semionotiform fishes and the origin of gars (Lepisosteidae). Naturwissenschaften, 97:1035-1040.

Chalifa, Y. and Tcherenov, E. 1982. Pachyamia latimaxillaris, new genus and species (Actinopterygii: Amiidae), from the Cenomanian of Jerusalem. Journal of Vertebrate Paleontology, 2:269-285.

Chellouche, P., Fürsich, F.T., and Mäuser, M. 2012. Taphonomy of neopterygian fishes from the Upper Kimmeridgian Wattendorf Plattenkalk of Southern Germany. Palaeobiodiversity and Palaeoenvironments, 92(1):99-117.

Cuny, G., Buffetaut, E., Cappetta, H., Martin, M., Mazin, J.M., and Rose, J.M. 1991. Nouveaux restes de Vertébrés du Jurassique terminal du Boulonnais (Nord de la France). Neues Jahrbuch für Geologie und Paläontologie, Abhandlungen, 180(3):323-347.

Dietl, G. and Schweigert, G. 2004 . The Nusplingen lithographic limestone - a "fossil lagerstaette" of late Kimmeridgian age from the Swabian Alb (Germany). Rivista Italiana di Paleontologia e Stratigrafia, 110(1):303-309.

Dineley, D. and Metcalf, S. 1999. Fossil Fishes of Great Britain, Geological Conservation Review Series, No. 16, Joint Nature Conservation Committee, Peterborough, 675 pp.

Ebert, M. and Kölbl-Ebert, M. 2012. Grabunsbericht Ettling 2012: Fund-Highlights und neue Forschungsergebnisse. Archaeopteryx, 30:23-37.

Fabre, J.A., de Broin, F., Ginsburg, L., and Wenz, S., 1982. Les vertebres du Berriasien de Canjuers (Var, France) et leur environnement. Geobios, 15(6):891923.

Fricke, K. 1876. Die fossilen Fische aus den oberen Juraschichten von Hannover. Palaeontographica, 22:45-87.

Gemmellaro, G.G. 1871. Studi paleontologici sulla fauna del Calcare a Terebratula janitor del nord di Sicilia. Giornale di Scienze Naturali ed Economiche 6:153187.

Grande, L. and Bemis, W.E. 1998. A comprehensive phylogenetic study of amiid fishes (Amiidae) based on comparative skeletal anatomy. An empirical search for interconnected patterns of natural history. Society of Vertebrate Paleontology Memoir 4: i-x, 1690; supplement to Journal of Vertebrate Paleontology, 18(1).

Heimberg, G. 1949. Neue Fischfunde aus dem Weissen Jura zeta von Württemberg. Palaeontographica, A, 97:75-98.

Heineke, E. 1906. Die Ganoiden und Teleostier des lithografischen Schiefers von Nusplingen. Geolo- 
gische und Palaeontologische Abhandlungen Jena (N F), 8:159-214.

Jain, S.L. and Robinson, P.L. 1963. Some new specimens of the fossil fish Lepidotes from the English Upper Jurassic. Proceeding of the Royal Society of London 141:119-135.

Kin, A. and Błażejowski, B. 2012. „Polskie Solnhofen”. Przegląd Geologiczny, 60(7):375-379.

Kin, A. and Błażejowski, B. 2014. The Horseshoe Crab of the genus Limulus: living fossil or stabiliomorph? PLOS ONE 9(10): e108036.

Kin, A., Błażejowski, B., and Binkowski, M. 2012. 'Polish Solnhofen': a long-awaited alternative?. Geology Today, 28(3):91-94.

Kin, A., Gruszczyński, M., Martill, D., Marshall, J., and Błażejowski, B. 2013. Palaeoenvironment and taphonomy of a Late Jurassic (Late Tithonian) Lagerstätte from central Poland. Lethaia, 46:71-81.

Klug, S. and Kriwet, J. 2012. An offshore fish assemblage (Elasmobranchii, Actinopterygii) from the Late Jurassic of NE Spain. Paläontologische Zeitschrift, 287 (2):235-257.

Kriwet, J. 1998. Late Jurassic Elasmobranch and Actinopterygian fishes from Portugal and Spain. Cuadernos Geología Ibérica, 24:241-260.

Kriwet, J. 2000. The fish fauna from the Guimarota mine, p. 41-50. In Martin, Th. and Krebs, B. (ed.), Guimarota, A Jurassic ecosystem. Verlag Dr. Friedrich Pfeil, München.

Kriwet, J. 2002. Pycnodont fish remains (Neopterygii: Pycnodontiformes) from the Upper Jurassic of the Lusitanian basin. Neues Jahrbuch für Geologie und Paläontologie, Monatshefte 10:577-587.

Kriwet, J. 2005. An amioid fish (Neopterygii, Amiiformes) from the Late Jurassic of the Iberian Peninsula. Geobios 38:99-106.

Kriwet, J. 2008. The dentition of the enigmatic pycnodont fish Athrodon wittei (Fricke, 1876) (Neopterygii; Pycnodontiformes), from the Late Jurassic of NW Germany. Fossil Record 11(2):61-66.

Lambers, P.H. 1994. The halecomorph fishes Caturus and Amblysemius in the lithographic limestone of Solnhofen (Tithonian), Bavaria. Geobios, 27, Supplement 1:91-99.

Lambers, P.H. 1998. The genus Furo (Pisces, Halecomorphi) from the Upper Jurassic Plattenkalke of Germany. Oryctos, 1:23-35.

Lambers, P.H. 1999. The actinopterygian fish fauna of the Late Kimmeridgian and Early Tithonian 'Plattenkalke' near Solnhofen (Bavaria, Germany: state of the art.). Geologie en Mijnbouw, 78:215-229.

Lane, J.A. and Ebert, M. 2012. Revision of Furo muensteri (Halecomorphi, Ophiopsidae) from the Upper Jurassic of Western Europe, with comments on the genus. Journal of Vertebrate Paleontology 32(4):799819.

Licht, M. 2011. A short contribution about the pycnodont fishes (Actinopterygii, Neopterygii) from Lower Sax- ony (NW-Germany) described by Fricke (1876). Studia Geologica Salmanticensia 47(1):69-76.

Martin-Abad, H. and Poyato-Ariza, F.J. 2013. Historical patterns of distribution in Pycnodontiform and Amiiform fishes in the context of moving plates. Geologica Belgica 16:217-226.

Mudroch, A. and Thies, D. 1996. Knochenfischzähne (Osteichthyes, Actinopterygii) aus dem Oberjura (Kimmeridgium) des Langenbergs bei Oker (Norddeutschland). Geologica et Palaeontologica, 30:239265.

Müller, M.M. 2011. The fish fauna of the Late Jurassic Solothurn Turtle Limestone (NW Switzerland). Swiss Journal of Geosciences, 104 (Suppl. 1):133-146.

Munnecke, A., Westphal, H., and Kölbl-Ebert, M. 2008. Diagenesis of plattenkalk: examples from the Solnhofen area (Upper Jurassic, S-Germany). Sedimentology, 55:1931-1946.

Ørvig, T. 1978. Microstructure and growth of the Dermal Skeleton in Fossil Actinopterygian Fishes: Birgeria and Scanilepis. Zoologica Scripta, 7:33-56.

Peyer, K., CHarbonnier, S., Allain, R., Läng, E., and Vacant, R. 2014. A new look at the Late Jurassic conservation Lagerstätte (Tithonian, Var, France). Comptes Rendus Palevol http://dx.doi.org/10.1016/ j.crpv.2014.01.007

Pharisat, A. 1975. Dents de sélaciens et d'holostéens fossiles du Kimméridgien de la carrière de la Baume à Audincourt. Annales Scientifiques de l'Université de Besançon Géologie, série 3, 23:99-106.

Pictet, F.J. and Jaccard, A. 1860. Description de quelques debris de reptiles et poissons fossiles trouvés dans l'étage Jurassique supérieur (Virgulien) du Jura Neuchatelois. Gene?ve : J. Kessmann, 1860. $85 \mathrm{pp}$.

Poyato-Ariza, F.J. and Martín-Abad, H. 2013. History of two lineages: Comparative analysis of the fossil record in Amiiformes and Pycnodontiformes (Osteichthyes, Actinopterygii). Spanish Journal of Palaeontology 28:79-90.

Prasad, G.V.R., Manhas, B.K., and Arratia, G. 2004. Elasmobranch and actinopterygian remains from the Jurassic and Cretaceous of India, p. 625-638. In Arratia, G. and Tintori, A. (ed.), Mesozoic Fishes 3 Systematics, Palaeonvironments and Biodiversity.

Priem, F. 1912. Sur des poissons des terrains Secondaires du sud de la France. Bulletin de la Societé géologique de France, sér. 4, 12:250-271.

Priem, F. 1917. Sur des poissons des terrains Secondaires du sud de la France. (Note complémentaire) Bulletin de la Societé géologique de France, sér. 4, 16:286-297.

Quanguo, LI, 2009. A new parasemionotid-like fish from the Lower Triassic of Jurong, Jiangsu province, South China. Palaeontology, 52(2):369-384.

Sasagawa, I., Ishiyama, M., Yokosuka, H., Mikami, M., and Uchida, T. 2009. Tooth enamel and enameloid in actinopterygian fish. Frontiers of Materials Science in China, 3:174-182. 
Sauvage, H.E. 1893. Note sur quelques Poissons du Calcaire bitumineux d'Orbagnoux (Ain). Bulletin de Societé d'Histoire Naturelle d'Autun 7:427-443.

Sauvage, H.E. 1902. Recherches sur les vertébrés du Kimméridgien supérieur de Fumel (Lot-et-Garonne). Mémoires de la Société géologique de France. Paléontologie, 25, $32 \mathrm{pp}$.

Shellis, R.P. and Miles, A.E.W. 1974. Autoradiographic study of the formation of enameloid and dentine matrices in teleost fishes using tritiated amino acid. Proceedings of the Royal Society of London $B$. 185:51-72.

Sutton, M.D., Rahman, I., Garwood, R.J. 2014. Techniques for Virtual Palaeontology. Wiley-Blackwell, $208 \mathrm{pp}$.

Thies, D. and Mudroch, A. 1996. Actinopterygian teeth from the Late Jurassic (Kimmeridgian) of N-Germany, p.105-114. In Arratia, G. and Viohl, G. (ed.), Mesozoic Fishes - Systematics and Paleoecology. Proceedings of the international meeting, Eichstätt 1993.

Vullo, R., Abit, D., Ballèvre, M., Billon-Bruyat, J.-.P., Bourgeais, R., Buffetaut, E., Daviero-Gomez, V., Garcia, G., Gomez, B., Mazin, J.-M., Morel, S., Nèraudeau, D., Pouech, J., Rage, J.-C., Schnyder, J., and Tong, H. 2014. Palaeontology of the Purbecktype (Tithonian, Late Jurassic) bonebeds of Chassiron (Oléron Island, western France). Comptes Ren- dus Palevol. http://dx.doi.org/10.1016/ j.crpv.2014.03.003

Wenz, S., Bernier, P., Barale, G., Bourseau, J.-P. Buffetaut, E., Gaillard, C., and Gall, G.-C. 1993. L' ichthyofaune des calcaires lithographiques du Kimméridgien supérieur de Cerin (Ain, France). Geobios, Mém. Spec. 16:61-70.

Wenz, S., Breton, G., and Lepage, G. 1987. Presence du genre Caturus (Pisces, Actinopterygii, Caturidae) dans le Kimmeridgien superieur des environs du Havre (Normandie, France). Bulletin trimestriel de la Société géologique de Normandie et des Amis du Muséum du Havre, 74(1):21-27.

Woodward, A.S. 1893. On some British Upper-Jurassic fish-remains, of the genera Caturus, Gyrodus and Notidanus, Annals and Magazine of Natural History, series $6,12: 398-402$.

Woodward, A.S. 1895. Catalog of fossil fishes in the British Museum (Natural History), 3. xlii + 554 pp. London: British Museum (Natural History).

Woodward, A.S. 1897. A contribution to the osteology of the Mesozoic amioid fishes Caturus and Osteorachis. II. Osteorachis leedsi, sp. n., from the Oxford Clay of Peterborough. Annals and Magazine of Natural History ser. 6, 19:379-387.

Woodward, A.S. 1915-1917. The fossil fishes of the English Wealden and Purbeck Formations. London. $148 \mathrm{pp}$. 


\section{SUPPLEMENTAL MATERIAL}

Caturus sp. (top) and Furo sp. (bottom). See palaeo-electronica.org/content/2015/1354-jurassicfish-xray for animation.

Caturus
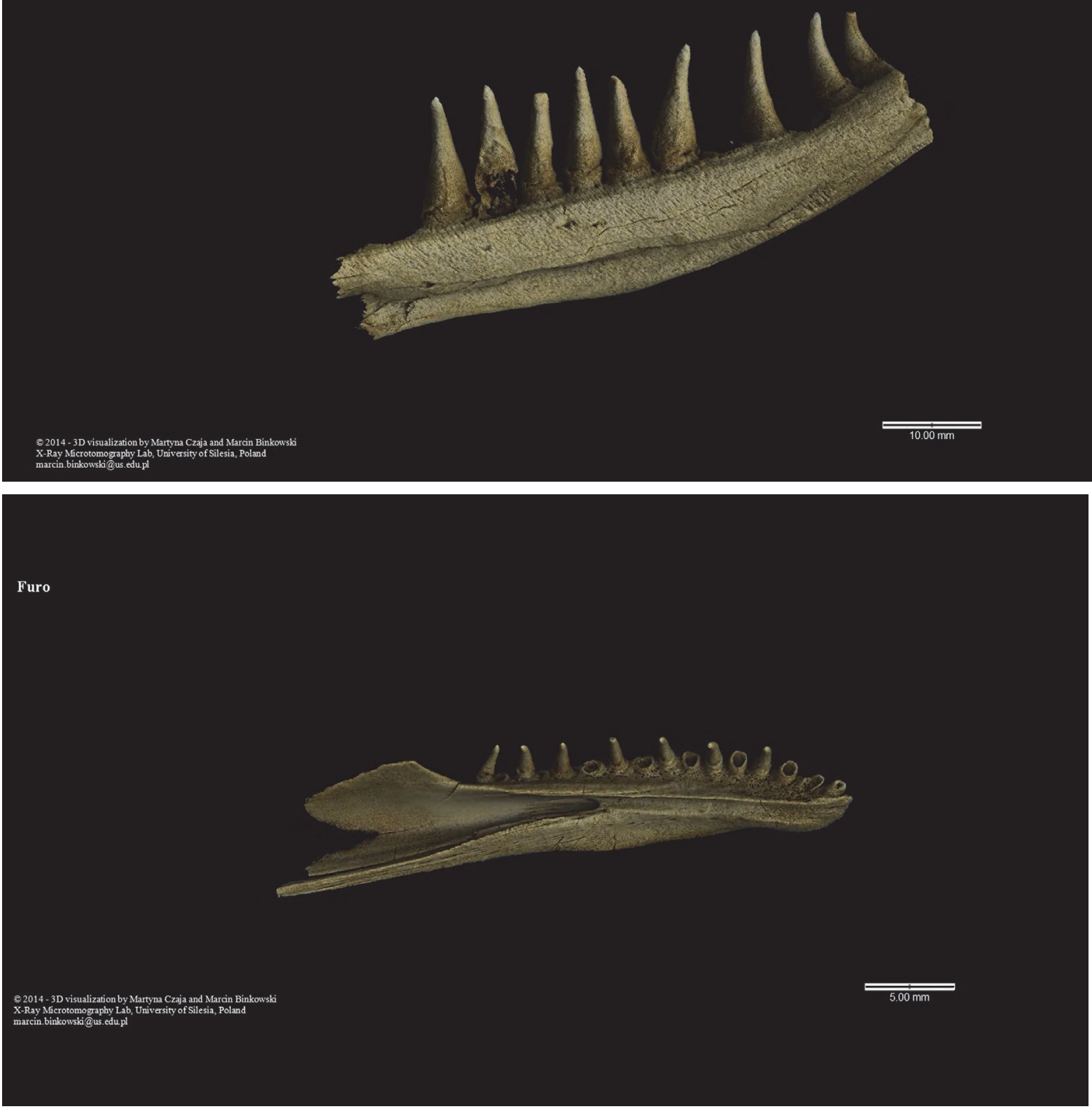